\title{
Treatment of Geographic Atrophy: What's on the Horizon?
}

\author{
Mariana R. Thorell • Philip J. Rosenfeld
}

Published online: 19 January 2014

(c) Springer Science+Business Media New York 2014

\begin{abstract}
Currently, there is no treatment to stop the progression of geographic atrophy, the advanced form of non-exudative (dry) age-related macular degeneration. Several promising therapies are being investigated in clinical trials such as antioxidants, neuroprotection agents, complement inhibitors, vascular enhancers, visual cycle modulators, and stem cell therapies. This review discusses the possible treatments that may potentially be available in the future to prevent disease progression.
\end{abstract}

Keywords Treatment of geographic atrophy - Agerelated macular degeneration (AMD) - Dry AMD . Ophthalmology $\cdot$ Cell therapies

\section{Introduction}

Age-related macular degeneration (AMD) is the leading cause of irreversible blindness among the elderly [1]. The non-exudative (dry) stage of AMD is the initial stage of the disease and the most common form of AMD, which can then progress to either advanced dry AMD, known as geographic atrophy (GA), or neovascular AMD. Currently, there is no approved treatment to stop the progression of dry AMD. Several mechanisms have been proposed to explain the pathogenesis of AMD, which is characterized by the loss of photoreceptors, retinal pigment epithelium and choriocapillaris in the central macula.

M. R. Thorell · P. J. Rosenfeld ( $₫)$

Bascom Palmer Eye Institute, University of Miami Miller School of Medicine, Miami, FL, USA

e-mail: prosenfeld@med.miami.edu
These pathogenic mechanisms include oxidative damage, the accumulation of toxic visual cycle byproducts such as lipofuscin, choroidal vascular insufficiency and chronic inflammation, with dysregulation of the complement system playing a major role [2]. Currently, the only published and recommended treatments to slow the progression of the disease are the use of oral supplements based on the AREDS2 [3••], cessation of smoking and a healthy diet rich in green leafy vegetables. However, several promising therapies to treat dry AMD are currently in clinical trials.

\section{Antioxidant Drugs}

Oxidative stress and the depletion of vital micronutrients may play a role in the pathogenesis of dry AMD leading to the dysfunction of RPE cells, which could accelerate the development of AMD [4-6]. The Age-Related Eye Disease Study (AREDS) was a phase III clinical trial that reduced the risk of progression to advanced AMD using oral supplementation with antioxidants and vitamins (beta-carotene, vitamin $\mathrm{C}$ and vitamin $\mathrm{E}$ ), as well as minerals (zinc and copper) [7]. In the second study (known as AREDS2), omega-3 fatty acids were shown to have no added benefit, while the macular xanthophylls (lutein and zeaxanthin) was found to be a safe and effective alternative to beta-carotene, which had been linked to lung cancers in smokers and former smokers $[3 \cdot \bullet]$.

OT-551, a synthetic lipophilic, disubstituted hydroxylamine, was developed as an antioxidant, formulated as an eye drop and used in a phase II study (NTC00306488) designed to test whether OT-551 could slow the progression of GA in eyes with AMD. The drug showed no benefit as a treatment for GA [8]. See Table 1. 
Table 1 Antioxidants

\begin{tabular}{lllllll}
\hline Drug & Mechanism of action & Administration & Clinical study phase & Clinical trial identifier & Sponsor & Subject condition \\
\hline AREDS2 & Antioxidant & Oral & Phase III & NCT00345176 & National Eye Institute & Drusen \\
OT-551 & Antioxidant & Topical & Phase II & NCT00306488 & Othera & Pharmaceuticals \\
& & & & & Bilateral GA & \\
\hline
\end{tabular}

Table 2 Neuroprotective drugs

\begin{tabular}{|c|c|c|c|c|c|c|}
\hline Drug & Mechanism of action & Administration & $\begin{array}{l}\text { Clinical study } \\
\text { phase }\end{array}$ & $\begin{array}{l}\text { Clinical trial } \\
\text { identifier }\end{array}$ & Sponsor & $\begin{array}{l}\text { Subject } \\
\text { condition }\end{array}$ \\
\hline Brimonidine tartrate & $\begin{array}{l}\alpha-2 \text { adrenergic receptor } \\
\text { agonist }\end{array}$ & $\begin{array}{l}\text { Intravitreal } \\
\text { implant }\end{array}$ & Phase II & NCT00658619 & Allergan & Bilateral GA \\
\hline CNTF (NT-501) & $\begin{array}{l}\text { Rescues photoreceptors } \\
\text { from degeneration }\end{array}$ & $\begin{array}{l}\text { Intravitreal } \\
\text { implant (ECT) }\end{array}$ & Phase II & NCT00447954 & $\begin{array}{l}\text { Neurotech } \\
\text { pharmaceuticals }\end{array}$ & GA \\
\hline GSK933776 & $\begin{array}{l}\text { Humanized IgG1 mAb } \\
\text { against } \mathrm{A} \beta \text { N-terminus }\end{array}$ & Intravenous & Phase II & NCT01342926 & GlaxoSmithKline & GA \\
\hline \multirow[t]{3}{*}{ RN6G } & \multirow[t]{3}{*}{$\mathrm{A} \beta$ peptides antibody } & \multirow[t]{3}{*}{ Intravenous } & Phase I & NCT00877032 & Pfizer & GA \\
\hline & & & Phase I & NCT01003691 & Pfizer & GA \\
\hline & & & Phase II & NCT01577381 & Pfizer & GA \\
\hline
\end{tabular}

\section{Neuroprotective Drugs}

Neuroprotective drugs appear to act by preventing the apoptosis of viable RPE cells and photoreceptors and preserving the macular function [9]. Brimonidine tartrate is an alpha-2 adrenergic receptor agonist and is the same substance that is available as an eye drop at different concentrations for the treatment of open angle glaucoma.

Brimonidine has been shown to protect photoreceptors from retinal degeneration in animal models by stimulating the production of neurotrophic factors [10], but the precise mechanism is still unknown. Brimonidine tartrate was formulated as an intravitreal implant, and this biodegradable delivery device was used in a clinical trial in an attempt to slow the progression of GA in eyes with AMD. Since the results of the phase II trial (NCT00658619) showed equivocal results, a second study is planned.

Ciliary neurotrophic factor (CNTF/NT-501) is a cytokine member of the IL-6 family of neuropoietic cytokines that acts to preserve photoreceptor cells from retinal degeneration [11••]. CNTF receptors were identified on Müller glial membranes and on rod and cone photoreceptors [12]. A phase II study (NCT00447954) was performed to evaluate the safety and effectiveness of CNTF implants in preserving the vision of subjects with atrophic AMD. The implant of encapsulated human NTC-201 cells releasing CNTF was well tolerated and resulted in a dose-dependent increase in retinal thickness. Visual acuity was stabilized (loss of less than 15 letters) in the high-dose group $(96.3 \%)$ when compared with the low-dose $(83.3 \%)$ and sham $(75 \%)$ group, but the implant failed to slow the progression of GA.
RN6G (PF-04382923) is a humanized monoclonal antibody that binds with high affinity to amyloid- $\beta$ (A $\beta)$ peptides (A $\beta-40$ and $A \beta-42)$, which are implicated in the pathogenesis of neurodegenerative diseases such as Alzheimer's disease. The deposition of $A \beta$ could play a role in drusen biogenesis, atrophy of the RPE and the pathogenesis of AMD [13]. The intravenous infusion aims to prevent $A \beta$ accumulation in the macula and remove existing $A \beta$. Two phase I clinical trials have been completed (NCT00877032/ NCT01003691), and a phase II trial is currently recruiting patients (NCT01577381) to evaluate the safety and tolerability of multiple doses of RN6G in subjects with GA due to AMD. No results have been published yet.

GSK933776 is another humanized monoclonal antibody that is directed against the $\mathrm{N}$-terminal sequence of amyloid- $\beta$. A phase II multicenter, randomized, double-masked, placebo-controlled study is underway in patients with GA (NCT01342926). The primary endpoint of the study is the change in the area of GA compared with baseline. Patients are treated monthly with GSK933776 (3-6 mg/kg intravenously) or placebo and then followed for 18 months. See Table 2.

\section{Drugs that Suppress Inflammation}

The complement cascade is likely to play a role in the pathogenesis of dry AMD. Studies demonstrating an association between AMD and certain at-risk alleles of genes encoding complement proteins have led to strategies that inhibit complement activation by targeting complement components [14]. 
Eculizumab (Soliris) is a humanized monoclonal antibody derived from a murine anti-human C5-specific antibody [15]. By binding C5, eculizumab prevents the cleavage of C5 into C5a and C5b and prevents the downstream complement activation and formation of the membrane attack complex (MAC). Eculizumab is approved by the Food and Drug Administration (FDA) for the intravenous treatment of paroxysmal nocturnal hemoglobinuria and alpha-hemolytic uremic syndrome. A phase II clinical trial, the Complement Inhibition with Eculizumab for the Treatment of Non-exudative Macular Degeneration (COMPLETE) study (NCT00935883), evaluated the safety and efficacy of the intravenously infused drug in preventing the growth of GA and reducing drusen volume. This randomized, double-arm study enrolled 60 patients (30 patients with GA and 30 patients with drusen). A 2:1 randomization resulted in 20 patients in each cohort receiving intravenous eculizumab and 10 patients in each cohort receiving intravenous saline placebo [16••]. Eculizumab was well tolerated, but did not reduce the growth rate of GA, nor did it reduce the volume of drusen. In this study, no association was observed between the number of at-risk alleles carried by the subjects and the growth rate of GA; however, there was an association between the increase in drusen volume and the number of complement factor $\mathrm{H}$ at-risk alleles carried by the subjects.

LFG316 is a fully human antibody that also targets the complement factor $\mathrm{C} 5$. A phase 1 dose escalation trial has been completed (NCT01255462), and a phase II trial (NCT01527500) to evaluate the ability of LFG316 to reduce the growth of GA with monthly intravitreal injections during a 12-month period is ongoing. The estimated primary completion date is June 2014.

ARC1905 is an anti-C5 pegylated aptamer that was investigated in a randomized phase I clinical trial (NCT00950638) to evaluate the safety and tolerability of intravitreal injection in subjects with GA. This study has been completed, but results have not been released.

FCFD4514S (lampalizumab) is an antigen-binding fragment (Fab) of a humanized, monoclonal antibody directed against complement factor $\mathrm{D}$, a rate-limiting enzyme involved in the activation of the alternative complement pathway. A phase I study demonstrated that the intravitreal injection of the drug in a single dose was safe and well tolerated up to a dose of $10 \mathrm{mg}$ with no related ocular or systemic adverse events [17]. The results of a phase II clinical trial (NCT01602120), designed to assess the long-term safety and tolerability of repeated intravitreal injections of lampalizumab for the treatment of GA, were recently presented at the 31st Annual Meeting of the American Society of Retina Specialists in Toronto, Ontario, Canada. Subjects received intravitreal injections of lampalizumab (10 mg) either monthly or every other month for 18 months. This randomized, multicenter, single-masked, controlled study showed a positive outcome in slowing the progression of GA in eyes injected every month with lampalizumab. The drug resulted in a $20.4 \%$ reduction rate in the growth of GA as assessed with fundus autofluorescence at 18 months $(P<0.1170$, statistically significant pre-specified protocol criteria). No effect was observed in the group treated every other month. In a subset of patients carrying the at-risk allele for complement factor I (CFI), which was present in $57 \%$ of the subjects, the treatment effect increased to a $44 \%$ reduction in growth rate $(P<0.005)$ compared with a $20.4 \%$ reduction found in the all the monthly treated subjects at 18 months. In addition, when subjects with this CFI at-risk allele and baseline best corrected visual acuity of 20/50-20/100 were compared with sham-injected subjects, the reduction in the growth rate of GA increased to $54 \%(P<0.005)$.

Iluvien (fluocinolone acetonide) is being studied as a possible treatment for patients with bilateral GA due to AMD in a phase II clinical trial (NCT00695318). The randomized, double-masked, interventional study is evaluating the safety and efficacy of the fluocinolone acetonide intravitreal implant $(0.2$ and $0.5 \mu \mathrm{g} /$ day $)$ compared with sham injection for reducing the growth rate of GA.

Sirolimus (rapamycin), an immunosuppressive agent, is a macrolide fungicide that inhibits the mammalian target of rapamycin (mTOR) [18, 19] and is being studied in patients with GA due to AMD. A phase I/II pilot study (NCT01445548) is underway in a single center to evaluate six patients with bilateral GA. One eye of each participant was randomly assigned to receive the intravitreal injection of Sirolimus, and the other eye serves as a control. The study eye receives the drug injection at baseline and every 2 months thereafter. The outcomes will be evaluated at completion of 12 months of treatment. A multi-center, randomized, singlemasked, phase II clinical trial (NCT01675947) is enrolling participants with GA to receive monthly intravitreal injection of Sirolimus or a subconjuntival sham injection during the 24-month study period. The endpoints for the two Sirolimus studies are the rate of change in the GA area and the change in visual acuity. See Table 3.

\section{Drugs that Increase Choroidal Blood Flow}

Recent studies have investigated whether a decrease in choroidal circulation may be involved in the development and progression of AMD [20, 21]. This theory presumes that the administration of vasodilators may restore the choroidal blood flow, avoiding the release of vascular endothelial growth factor (VEGF) and the consequent neovascularization. 
Table 3 Drugs that suppress inflammation

\begin{tabular}{|c|c|c|c|c|c|c|}
\hline Drug & Mechanism of action & Administration & $\begin{array}{l}\text { Clinical } \\
\text { study phase }\end{array}$ & $\begin{array}{l}\text { Clinical trial } \\
\text { identifier }\end{array}$ & Sponsor & $\begin{array}{l}\text { Subject } \\
\text { condition }\end{array}$ \\
\hline ARC1905 & Anti-C5 aptamer & $\begin{array}{c}\text { Intravitreal } \\
\text { injection }\end{array}$ & Phase I & NCT00950638 & Ophthotec & $\begin{array}{l}\text { GA and/or } \\
\text { drusen }\end{array}$ \\
\hline Eculizumab (Soliris) & Monoclonal antibody against C5 & Intravenous & Phase II & NCT00935883 & Alexion & $\begin{array}{l}\text { GA or } \\
\text { drusen }\end{array}$ \\
\hline $\begin{array}{l}\text { FCFD4514S } \\
\text { (Lampalizumab) }\end{array}$ & Anti-factor D & $\begin{array}{l}\text { Intravitreal } \\
\text { injection }\end{array}$ & Phase II & NCT01602120 & Genentech & GA \\
\hline $\begin{array}{l}\text { Fluocinolone } \\
\text { acetonide (Iluvien) }\end{array}$ & $\begin{array}{l}\text { Supression of inflammation } \\
\text { glucocorticoid-mediated }\end{array}$ & $\begin{array}{c}\text { Intravitreal } \\
\text { injection }\end{array}$ & Phase II & NCT00695318 & $\begin{array}{l}\text { Alimera } \\
\text { Sciences }\end{array}$ & GA \\
\hline LFG316 & Human antibody against C5 & $\begin{array}{l}\text { Intravitreal } \\
\text { injection }\end{array}$ & Phase II & NCT01527500 & Novartis & GA \\
\hline \multirow[t]{2}{*}{ Sirolimus } & mTOR inhibitor & $\begin{array}{c}\text { Intravitreal } \\
\text { injection }\end{array}$ & Phase I/II & NCT01445548 & $\begin{array}{l}\text { National Eye } \\
\text { Institute }\end{array}$ & $\begin{array}{l}\text { Bilateral } \\
\text { GA }\end{array}$ \\
\hline & & & Phase II & NCT01675947 & $\begin{array}{l}\text { National Eye } \\
\text { Institute }\end{array}$ & GA \\
\hline
\end{tabular}

Table 4 Vascular enhancer

\begin{tabular}{lllllll}
\hline Drug & Mechanism of action & Administration & $\begin{array}{l}\text { Clinical study } \\
\text { phase }\end{array}$ & Clinical trial identifier & Sponsor & Subject condition \\
\hline MC-1101 & $\begin{array}{l}\text { Choroidal blood flow } \\
\text { modulator }\end{array}$ & Topical & Phase II/III & NCT01601483 & MacuCLEAR & $\begin{array}{c}\text { Non-exudative } \\
\text { AMD }\end{array}$ \\
\hline
\end{tabular}

MC-1101 is a topically administered eye drop developed to increase choroidal blood flow. Originally developed as an antihypertensive drug, the mechanism of action is associated with the generation of nitric oxide (NO) to produces vasodilation. A phase I clinical trial (NCT01013376) has shown that MC-1101 is safe and well tolerated in humans. A phase II/III trial (NCT01601483) is currently ongoing to evaluate the efficacy and safety of topical $1 \%$ MC-1101 administered three times a day. The study is a randomized, doublemasked investigation of patients with mild to moderate nonexudative AMD, and visual function is the primary outcome after 2 years. See Table 4.

\section{Visual Cycle Modulators}

The goal of visual cycle modulation is to reduce the accumulation of toxic fluorophores in the RPE and prevent the loss of the RPE and photoreceptors. These fluorophores include lipofuscin and its major component, A2E ( $N$-retinylidene- $N$-retinylethanolamine), a cytotoxin generated from retinoid by-products of the visual cycle [14, 22].

ACU-4429 (emixustat hydrochloride) is a non-retinoid molecule developed to be a selective visual cycle modulator that targets rod cells. The oral administrations of ACU-4429 is intended to reduce the accumulation of toxic products (A2E) by binding and inhibiting the activity of the isomerase known as the RPE-specific $65-\mathrm{kDa}$ protein (RPE65), thereby preventing the conversion of all-transretinol to 11-cis-retinol [2]. However, the side effects of reducing the levels of 11-cis retinol include difficulties with dim light vision, dark adaptation and dyschromotopia. A phase I trial (NCT00942240) with healthy volunteers compared oral emixustat with placebo and demonstrated that all the doses of emixustat $(5,10,20,30$ and $40 \mathrm{mg})$ were well tolerated, and no serious adverse effects were identified [23, 24]. The visual symptoms presented during the study were transient. A subsequent phase II study (NCT01002950) enrolled 72 subjects with GA and has been completed, but no results have been published as yet. A large phase II/III trial (NCT01802866) was started in February 2013 and is designed to compare the efficacy and safety of ACU-4429 with placebo and to determine whether the drug reduces the rate of progression of GA in subjects with dry AMD.

Fenretinide [ $N$-(4-hydroxyphenyl)-retinamide] is a synthetic drug that binds to retinol-binding protein 4 (RBP4), displaces all-trans retinol from RBP4 and disrupts the retinol-dependent RBP4-transthyretin (TTR) interaction, thereby preventing transport of all-trans-retinol in the circulation [25]. In an animal study, fenretinide reduced the bisretinoid production and accumulation of lipofuscin and A2E in the RPE [26]. A randomized, double-masked, phase II study (NCT00429936) comparing the safety and efficacy 
Table 5 Visual cycle modulators

\begin{tabular}{|c|c|c|c|c|c|c|}
\hline Drug & Mechanism of action & Administration & $\begin{array}{l}\text { Clinical study } \\
\text { phase }\end{array}$ & $\begin{array}{l}\text { Clinical trial } \\
\text { identifier }\end{array}$ & Sponsor & $\begin{array}{l}\text { Subject } \\
\text { condition }\end{array}$ \\
\hline \multirow{2}{*}{$\begin{array}{l}\text { ACU-4429 (emixustat } \\
\text { hydrocloride) }\end{array}$} & \multirow{2}{*}{$\begin{array}{l}\text { Non-retinoid molecule/ } \\
\text { inhibits activity of RPE65 }\end{array}$} & \multirow[t]{2}{*}{ Oral } & Phase II & NTC01002950 & Acucela & GA \\
\hline & & & Phase II/III & NCT01802866 & Acucela & GA \\
\hline Fenretinide & $\begin{array}{l}\text { Retinol analog (inhibits } \\
\text { binding of retinol to RBP) }\end{array}$ & Oral & Phase II & NCT00429936 & Sirion therapeutics & GA \\
\hline
\end{tabular}

Table 6 Cell therapies

\begin{tabular}{|c|c|c|c|c|c|c|}
\hline Drug & Mechanism of action & Administration & $\begin{array}{l}\text { Clinical study } \\
\text { phase }\end{array}$ & $\begin{array}{l}\text { Clinical trial } \\
\text { identifier }\end{array}$ & Sponsor & $\begin{array}{l}\text { Subject } \\
\text { condition }\end{array}$ \\
\hline HuCNS-SC cells & $\begin{array}{l}\text { HuCNS-SC cells transplantation } \\
\text { into subretinal space }\end{array}$ & $\begin{array}{r}\text { Stem cell } \\
\text { implant }\end{array}$ & Phase I/II & NCT01632527 & Stem cells & GA \\
\hline \multirow[t]{2}{*}{ MA09-hRPE cells } & $\begin{array}{l}\text { Transplantation of hESC-derived } \\
\text { RPE cells }\end{array}$ & $\begin{array}{r}\text { Stem cell } \\
\text { implant }\end{array}$ & Phase I/II & NCT01344993 & $\begin{array}{l}\text { Advanced cell } \\
\text { technology }\end{array}$ & GA \\
\hline & & & Phase I/II & NCT01674829 & $\begin{array}{l}\text { CHA Bio and } \\
\text { Diostech }\end{array}$ & GA \\
\hline
\end{tabular}

$C N T F$ ciliary neurotrophic factor, $E C T$ encapsulated cell technology, $I g G 1$ immunoglobulin $1, m A b$ monoclonal antibody, $A \beta$ amyloid- $\beta, C 5$ compliment factor 5, mTOR mammalian target of rapamycin, RPE retinal pigment epithelium, $H u C N S$-SC human neural stem cells, $h E S C$ human embryonic stem cell

of fenretinide with placebo has been completed. Subjects with GA received oral placebo or fenretinide (100$300 \mathrm{mg}$ ) daily for 24 months. The study showed that fenretinide was safe and found to produce dose-dependent reversible reduction in serum RBP-retinol that could be related to a trend in reducing the growth rates of GA [27]. However, no definitive treatment benefit was recognized. Potential side effects include night blindness and dry eye. See Table 5.

\section{Cell Therapies}

Cell therapy is also emerging as a treatment approach for dry AMD [28-30]. Stem cell therapy is being investigated as a way to replace damaged RPE cells, prevent progression of the disease and the deterioration of the photoreceptors, and sustain visual function [31].

MA09-hRPE, RPE cells derived from embryonic stem cells, have been transplanted to treat patients with dry AMD and Stargardt disease. Two clinical trials (NCT01344993 and NTC01674829) are currently underway to evaluate the safety and tolerability of subretinal transplantation of the human embryonic stem cell MA09-hRPE in eyes with GA secondary to AMD and Stargradt disease.

A phase I/II study of subretinal transplantation of human central nervous system (HuCNS-SC) stem cells (NCT01632527) in eyes with GA is currently underway and designed to evaluate the safety and efficacy of this treatment. The trial consists of two cohorts. Cohort I will include four subjects who will undergo transplant with 200,000 cells followed by four subjects who will undergo transplant with 1 million cells. Cohort II will include eight subjects who will undergo transplant with 1 million cells. See Table 6.

\section{Summary}

Several drugs are under investigation for the treatment of dry AMD. Antioxidants, neuroprotectors, complement inhibitors, vascular enhancers, visual cycle modulators and stem cells are some of the promising strategies that have been tried or are in clinical trials. To date, only the AREDS2 has convincingly demonstrated a benefit in slowing the progression of dry AMD to neovascular AMD, while the complement inhibitor lampalizumab has shown some preliminary evidence that it might slow the growth rate of GA. Results from several ongoing trials should be available in 2014.

Acknowledgments This study was supported in part by grants from Alexion Pharmaceuticals, GlaxoSmithKline, Acucela, Advanced Cell Technology, and Carl Zeiss Meditec, and consulting fees from Acucela to Philip Rosenfeld.

Disclosure Philip Rosenfeld has received or will receive research support from Alexion Pharmaceuticals, GlaxoSmithKline, Acucela, Advanced Cell Technology and Carl Zeiss Meditec. He also has received consulting fees from Acucela, Oraya, Roche, Sanofi/Genzyme, Merck, Boehringer Ingelheim, Bayer, Alcon and Chengdu Kanghong Biotech. Mariana R. Thorell claims no conflicts of interest. 
Human and Animal Rights and Informed Consent This article does not contain any studies with human or animal subjects performed by any of the authors.

\section{References}

Papers of particular interest, published recently, have been highlighted as:

- Of major importance

1. Bressler NM. Age-related macular degeneration is the leading cause of blindness. JAMA. 2004;291(15):1900-1.

2. Zarbin MA, Rosenfeld PJ. Pathway-based therapies for agerelated macular degeneration: an integrated survey of emerging treatment alternatives. Retina. 2010;30(9):1350-67.

3. •- The Age-Related Eye Disease Study. Lutein + zeaxanthin and omega-3 fatty acids for age-related macular degeneration: the age-related eye disease study 2 (AREDS2) randomized clinical trial. JAMA. 2013;309(19):2005-15. The study demonstrated that adding omega-3 fatty acids to the original AREDS formula had no additional benefit while lutein and zeaxanthin were found to be a safe and effective alternative to beta-carotene in slowing the progression to neovascular AMD.

4. Cao S, Walker GB, Wang X, Cui JZ, Matsubara JA. Altered cytokine profiles of human retinal pigment epithelium: oxidant injury and replicative senescence. Mol Vis. 2013;19:718-28.

5. Mettu PS, Wielgus AR, Ong SS, Cousins SW. Retinal pigment epithelium response to oxidant injury in the pathogenesis of early age-related macular degeneration. Mol Aspects Med. 2012;33(4): 376-98.

6. Evans JB, Syed BA. New hope for dry AMD? Nat Rev Drug Discov. 2013;12(7):501-2.

7. Chew EY, Clemons T, SanGiovanni JP, et al. The Age-Related Eye Disease Study 2 (AREDS2): study design and baseline characteristics (AREDS2 report number 1). Ophthalmology. 2012;119(11):2282-9.

8. Wong WT, Kam W, Cunningham D, et al. Treatment of geographic atrophy by the topical administration of OT-551: results of a phase II clinical trial. Invest Ophthalmol Vis Sci. 2010;51(12):6131-9.

9. Damico FM, Gasparin F, Scolari MR, Pedral LS, Takahashi BS. New approaches and potential treatments for dry age-related macular degeneration. Arquivos brasileiros de oftalmologia. 2012;75(1):71-6.

10. Saylor M, McLoon LK, Harrison AR, Lee MS. Experimental and clinical evidence for brimonidine as an optic nerve and retinal neuroprotective agent: an evidence-based review. Arch Ophthalmol. 2009; 127(4):402-6.

11. • Zhang K, Hopkins JJ, Heier JS, et al. Ciliary neurotrophic factor delivered by encapsulated cell intraocular implants for treatment of geographic atrophy in age-related macular degeneration. Proc Natl Acad Sci USA. 2011;108(15):6241-5. The encapsulated cell implant expressing ciliary neurotrophic factor in age-related macular degeneration patients with geographic atrophy was well tolerated and appeared to preserve vision but failed to slow the progression of GA in the study.

12. Beltran WA, Zhang Q, Kijas JW, et al. Cloning, mapping, and retinal expression of the canine ciliary neurotrophic factor receptor alpha (CNTFRalpha). Invest Ophthalmol Vis Sci. 2003; 44(8):3642-9.

13. Johnson LV, Leitner WP, Rivest AJ, Staples MK, Radeke MJ, Anderson DH. The Alzheimer's A beta -peptide is deposited at sites of complement activation in pathologic deposits associated with aging and age-related macular degeneration. Proc Natl Acad Sci USA. 2002;99(18):11830-5.

14. Zhang K, Zhang L, Weinreb RN. Ophthalmic drug discovery: novel targets and mechanisms for retinal diseases and glaucoma. Nat Rev Drug Discov. 2012;11(7):541-59.

15. Soliris (package insert). $2013 \mathrm{http}: / / \mathrm{www}$. soliris.net/indications/ soliris_pi.pdf\#page=7. Accessed Oct 28, 2013.

16. •• Yehoshua Z, de Amorim Garcia Filho CA, Portella Nunes R, et al. Systemic complement inhibition with eculizumab for geographic atrophy in age-related macular degeneration: The complete study. Ophthalmology. 2013 (in press). In the prospective investigation of the effects of the systemic complement inhibition with eculizumab, the drug was well tolerated with no related adverse events reported, but the treatment did not significantly decrease the growth rate of geographic atrophy during the 6 months of active treatment in the study.

17. Do DV, Pieramici DJ, van Lookeren Campagne M, et al. A phase Ia dose-escalation study of the anti-factor $\mathrm{d}$ monoclonal antibody fragment Fcfd4514s in patients with geographic atrophy. Retina. 2013 (in press).

18. Engelbert M. New hope for dry AMD patients. Retin Phys. 2011. http://www.retinalphysician.com/articleviewer.aspx?article $\mathrm{ID}=105162$. Accessed Oct 29, 2013.

19. Dugel PU. Sirolimus in the treatment of retinal diseases. mTOR inhibitors: a new class of therapeutics. Retin Today. 2009:38-41.

20. Xu W, Grunwald JE, Metelitsina TI, et al. Association of risk factors for choroidal neovascularization in age-related macular degeneration with decreased foveolar choroidal circulation. Am J Ophthalmol. 2010;150(1):40-7 e42.

21. Boltz A, Luksch A, Wimpissinger B, et al. Choroidal blood flow and progression of age-related macular degeneration in the fellow eye in patients with unilateral choroidal neovascularization. Invest Ophthalmol Vis Sci. 2010;51(8):4220-5.

22. Mata NL, Kubota R, Schneider S, Kissner J, Birch DG, Dugel PU. Pharmacodynamics of visual cycle modulation in the treatment of GA. Retin Phys. 2013;10:22-5.

23. Kubota R, Boman NL, David R, Mallikaarjun S, Patil S, Birch D. Safety and effect on rod function of ACU-4429, a novel smallmolecule visual cycle modulator. Retina. 2012;32(1):183-8.

24. Kubota R, Al-Fayoumi S, Mallikaarjun S, Patil S, Bavik C, Chandler JW. Phase 1, dose-ranging study of emixustat hydrochloride (Acu-4429), a novel visual cycle modulator, in healthy volunteers. Retina. 2013 (in press).

25. Berni R, Clerici M, Malpeli G, Cleris L, Formelli F. Retinoids: in vitro interaction with retinol-binding protein and influence on plasma retinol. FASEB J. 1993;7(12):1179-84.

26. Dobri N, Qin Q, Kong J, et al. A1120, a nonretinoid RBP4 antagonist, inhibits formation of cytotoxic bisretinoids in the animal model of enhanced retinal lipofuscinogenesis. Invest Ophthalmol Vis Sci. 2013;54(1):85-95.

27. Mata NL, Lichter JB, Vogel R, Han Y, Bui TV, Singerman LJ. Investigation of oral fenretinide for treatment of geographic atrophy in age-related macular degeneration. Retina. 2013;33(3): 498-507.

28. Du H, Lim SL, Grob S, Zhang K. Induced pluripotent stem cell therapies for geographic atrophy of age-related macular degeneration. Semin Ophthalmol. 2011;26(3):216-24.

29. Tibbetts MD, Samuel MA, Chang TS, Ho AC. Stem cell therapy for retinal disease. Curr Opin Ophthalmol. 2012;23(3):226-34.

30. Kvanta A, Grudzinska MK. Stem cell-based treatment in geographic atrophy: promises and pitfalls. Acta Ophthalmol. 2013 (in press).

31. Melville H, Carpiniello M, Hollis K, Staffaroni A, Golestaneh N. Stem cells: a new paradigm for disease modeling and developing therapies for age-related macular degeneration. J Transl Med. 2013;11:53. 